\title{
MARIAN STEPULAK \\ Rozwój czy kryzys duchowości katolickiej w kontekście nauczania Jana Pawła II
}

Rozwój duchowy można rozumieć na sposób czysto psychologiczny, przypisując mu wyłącznie status najwyższego poziomu organizacji osobowości a nawet najdoskonalszy sposób funkcjonowania osoby ludzkiej. W mojej propozycji jednak został przyjęty inny, specyficzny sposób rozumienia rozwoju duchowego. Odnosi się on bowiem do refleksji w duchu teologii duchowości katolickiej. W takim podejściu na szczególna uwage zasługuje problem genezy rozwoju duchowego, a także zwrócenie uwagi na glówne cele życia duchowego. Wydaje się, iż oryginalnym przedsięwzięciem jest przedstawienie dialogicznego rozumienia rozwoju duchowego wedlug następujacego porządku: pojęcie dialogu duchowego i dialog a rozwój osobowy.

Zasadniczy element mojej prezentacji zawarty jest jednak w ostatniej części odnoszącej się do rozwoju duchowości katolickiej w nauczaniu Jana Pawla II. Duchowość katolicka zostala poddana analizie w trzech następujących aspektach: duchowość laikatu, duchowość kaplańska oraz duchowość życia konsekrowanego.

\section{Ogólna problematyka rozwoju duchowego}

Rozwój duchowy zamyka calość problematyki wieloaspektowego rozumienia rozwoju. Po przedstawieni wcześniejszych aspektów rozwoju można dopiero dokonać w sposób adekwatny naukowej refleksji wlaśnie nad rozwojem duchowym. W poniższej tabeli podane są wedlug hierarchii ważności poszczególne sfery rozwojowe, od sfery rozwoju biotycznego, aż po rozwój duchowy. Można w tym kontekście powiedzieć, iż rozwój duchowy jest na szczycie hierarchii 
rozwoju osobowego, ale równocześnie można wyraźnie wskazać na fakt, że rozwój duchowy, to zupelnie inna jakość. Rozwój duchowy bowiem otwarty jest na Transcendencję, na inny wymiar i obszar relacji interpersonalnych. To wszystko powoduje, iż od strony metodologicznej można dokonać rozdziału rozwoju duchowego od pozostalych sfer rozwojowych czlowieka. W sensie merytorycznym jednak należy mieć przekonanie, iż rozwój duchowy nie jest czymś abstrakcyjnym, zaklada bowiem fakt istnienia konkretnej osoby ludzkiej ujętej w sposób holistyczny ${ }^{1}$, to znaczy ze wszystkimi sferami jego rozwoju. Nie przeszkodzi to jednak na przeprowadzenie analizy rozwoju duchowego $\mathrm{w}$ innym paradygmacie naukowym, charakterystycznym dla teologii duchowości. Stąd też rozwój duchowy należy rozumieć jako ustawiczne spotkanie życia nadprzyrodzonego, danego czlowiekowi z Boskiej inicjatywy, i życia naturalnego osoby ludzkiej. Inicjatywa Boga spotyka się z inicjatywą ludzką. Można by powiedzieć, że rozwój duchowy jest darem i zadaniem. Ma przy tym charakter integralny (holistyczny). W tym więc rozumieniu jest wlaściwie jedynym procesem, jaki można zaobserwować w czlowieku. Wszystkie bowiem sfery czlowieka przedstawione w tabeli są tylko częścią skladową wspólpracy chrześcijanina z Bożą laską.

\begin{tabular}{|c|l|}
\hline Sfera rozwojowa & \multicolumn{1}{|c|}{ Dziedziny i obszary rozwojowe } \\
\hline Rozwój biotyczny & $\begin{array}{l}\text { Zmiany jakościowe i ilościowe organizmu ludzkiego } \\
\text { w obszarze różnicowania się komórek, tkanek, po- } \\
\text { wstawania samoistnych układów, narządów, aż do } \\
\text { stanu coraz większej samodzielności ontogenetycznej. }\end{array}$ \\
\hline Rozwój poznawczy & $\begin{array}{l}\text { Stadia i fazy rozwojowe, mowy, uwagi, pamięci, } \\
\text { wyobraźni, percepcji, myślenia i inteligencji. }\end{array}$ \\
\hline Rozwój motywacyjno-emocjonalny & $\begin{array}{l}\text { Geneza i specyfika potrzeb, źródła i ksztaltowanie się } \\
\text { życia emocjonalnego osoby. }\end{array}$ \\
\hline Rozwój spoleczny & $\begin{array}{l}\text { Zródła i główne mechanizmy rozwoju spolecznego. } \\
\text { Kształtowanie się norm i hierarchii wartości społecz- } \\
\text { nych. }\end{array}$ \\
\hline Rozwój estetyczny & $\begin{array}{l}\text { Potrzeby i zainteresowania plastyczne, teatralne, } \\
\text { filmowe, literackie i muzyczne. Główne czynniki } \\
\text { rozwoju. }\end{array}$ \\
\hline Rozwój moralny & $\begin{array}{l}\text { Fazy i stadia rozwoju moralnego. Czynniki warunku- } \\
\text { iace rozwój moralny. }\end{array}$ \\
\hline Rozwój religijny & $\begin{array}{l}\text { Prawidlowości, normy rozwoju religijności i kryzysy } \\
\text { religijności. Fazy rozwoju życia religijnego człowie- } \\
\text { ka. }\end{array}$ \\
\hline ROzwój DUCHOWY & $\begin{array}{l}\text { Długotrwałe i dynamiczne procesy otwierania się na } \\
\text { zbawcze samoudzielanie się Boga. Uwarunkowania } \\
\text { rozwoju duchowego oraz kryzysy wiary. Etapy i drogi } \\
\text { rozwoju duchowego. }\end{array}$ \\
\hline
\end{tabular}

1 Twórca idei holizmu był Jan S m u ts (1926 r.), który zaproponowal słowo „holizm” od greckiego źródłosłowu ,holos”, oznaczającego „kompletny”, „,cały”, „całkowity”; Por. M. S te p u l a k: Podejście systemowe we wspólczesnej psychologii polskiej. Lublin 1995 s. 13. 
Wzrost i rozwój duchowy nie redukuje się ani do wysilku doskonalenia ontologicznego, jako wzrost w lasce uświęcającej. Nie ogranicza się także do postępu ascetycznego, rozważanego zwykle jako udoskonalenie cnót. Rozwój duchowy implikuje jedno $\mathrm{i}$ drugie, ale $\mathrm{w}$ istocie polega na personalnej relacji do Chrystusa we wspólnocie Kościola i jest skutkiem Jego zbawczej przyczynowości, najpełniej objawiającej się w sakramentach ${ }^{2}$. Rozwój duchowy, ogarnia różne elementy ludzkiej osobowości. Zmierza on w kierunku integracji (ale nie ujednolicenia). Podkreśla się, że w procesie holistycznego rozwoju duchowego można wyróżnić cztery podstawowe wymiary życia osoby ludzkiej:

- wymiar teologiczny;

- wymiar moralny;

- wymiar eklezjalny;

- wymiar psychologiczny.

Wymiary te są wspólzależne, ale pozostaja równocześnie autonomiczne. Oznacza to, że wzrost i rozwój w plaszczyźnie teologicznej nie musi oznaczać automatycznie wzrostu i rozwoju w plaszczyźnie psychologicznej. I odwrotnie. Z drugiej zaś strony rozwój psychiczny znacząco determinuje rozwój postaw teotropicznych.

M. Chmielewski wyraża przekonanie, iż wzrost i rozwój duchowy aktualizuje się angażując te same struktury i procesy psychiczne osoby. Stąd studium duchowości, zwlaszcza w zakresie rozwoju duchowego, coraz częściej i glębiej sięga do psychologii w trosce o to, by nie stracić z oczu rzeczywistego czlowieka, trzeba bowiem zdawać sobie sprawę, że duchowości, szczególnie zajmujacej się intensyfikacja personalnej relacji do Chrystusa zawsze grozi pokusa tworzenia antropologii odcieleśnionej, idealistycznej. Czlowiek duchowy, nie jest czlowiekiem odczlowieczonym. Jest czlowiekiem z tego świata, ale nie dla tego świata ${ }^{3}$.

Warto wspomnieć, iż w teologii duchowości przyjmuje się także pojęcie „postępu duchowego". Jest to jednak synonim rozwoju duchowego pojmowany jako przejście od istniejącego do doskonalszego stanu czlowieka, będące formą postępu w doskonalości na drogach życia duchowego. Obejmuje on proces rozwoju $\mathrm{w}$ zakresie intelektualnym, wolitywnym, emocjonalnym i kulturowym w dziedzinie przyrodzonej, a u czlowieka religijnego również $w$ dziedzinie nadprzyrodzonej ${ }^{4}$.

${ }^{2}$ Z. A l s z e g hy: Relaciones entre crecimiento psicológico y crecimiento e spiritual. Precisiones desde la teologia. "Vida Religiosa". R. 1977 nr 42 s. 338.

${ }^{3}$ M. C h m i e le w s k i: Vademecum duchowości katolickiej. Lublin 2004 s. 85-90.

${ }^{4}$ J. S t a n i sła w sk i: Duchowy postęp. W: Encyklopedia katolicka. T. 4. Lublin1985 s. 334. 


\section{Geneza rozwoju duchowego}

Efekty wspólpracy z laską Bożą w procesie rozwoju duchowego determinowane są przez ograniczenia skażonej przez grzech pierworodny natury ludzkiej. Maja one charakter obiektywny i subiektywny.

1. Uwarunkowania obiektywne rozwoju duchowego, są niezależne od czlowieka. Dzielą się na psychofizyczne, takie jak: pleć, wyposażenie genetyczne, wiek, osobowość, zdrowie psychosomatyczne oraz spolecznokulturowe, takie jak: kultura, wplyw środowiskowy (rodzina, grupy rówieśnicze itp.), pochodzenie geograficzne, wychowanie, a także wykształcenie. Biorąc pod uwage jedność psychofizyczną podmiotu duchowego nie można pomijać, ani nie doceniać czynników obiektywnych, jako to czynila średniowieczna ascetyka w formule fuga mundi $i^{5}$.

2. Uwarunkowania subiektywne rozwoju duchowego, za które osoba ponosi pelną odpowiedzialność, to: A) Nawrócenie - pierwszy szczebel w procesie rozwoju duchowego. Trudno bowiem bez wyraźnych owoców nawrócenia mówić o wejściu na drogę rozwoju duchowego „Wydajcie więc owoce godne nawrócenia; i nie próbujcie sobie mówić: Abrahama mamy za ojca, bo powiadam wam, że z tych kamieni może Bóg wzbudzić dzieci Abrahamowi" (Łk 3,8). B) Pragnienie doskonatości, które musi odznaczać się tym, że jest nadprzyrodzone, czyli wynika z motywacji wiary a nie z ludzkich względów; dominujące, tzn. jest silniejsze od innych pragnień. „Starajcie się naprzód o królestwo i o Jego sprawiedliwość, a to wszystko będzie wam dodane" (Mt 6,33; por Mt 13,44-46); stałe, czyli wymagajace wytrwałości, bo tylko w ten sposób osiaga się prawdziwe wartości; wzrastające - bez zatrzymywania się na osiagniętym poziomie. "Jezus mu odpowiedział: Ktokolwiek przykłada rękę do pluga, a wstecz się oglada, nie nadaje się do królestwa Bożego" (Łk 9,62); praktyczne, czyli oparte na realiach, rzeczywistych możliwościach podmiotu i dostosowane do jego drogi powolania. C) Życie sakramentalno-modlitewne - w porządku istotowym pierwszym i najważniejszym sakramentem jest Eucharystia, lecz w porządku genetycznym pierwszy jest chrzest święty. W nim wlaśnie dokonuje się inicjacja życia duchowego, do którego dochodzą pozostale sakramenty. Modlitwa jest także warunkiem sine qua non rozwoju duchowego. D) Asceza i podjęcie walki duchowej, aby usunać przeszkody dla owocnej wspólpracy z laska Boża. E) Apostolskie zaangażowanie w Kościele, to nieodlaczny wymiar życia duchowego, weryfikujący jego autentyczność. W miarę jak chrze-

${ }^{5}$ M. Ch m i e lew s k i: Rozwój duchowy [...]. W: Leksykon duchowości katolickiej. Red. M. C h m i e lew ski. Lublin-Kraków 2002 s. 764. 
ścijanin jednoczy się z Chrystusem w miłości, w takim stopniu sluży jego Mistycznemu Ciahu ${ }^{6}$.

\section{Cele życia duchowego}

Istotnych zagadnieniem związanym $\mathrm{z}$ rozwojem duchowym jest niewatpliwie cel życia duchowego. Można zatem mówić o trzech różnych celach. Pierwszy z nich można by nazwać celem dalszym i absolutnym, a jest nim chwala Boża. Dwa pozostale cele bliższe i względne to zbawienie i uświęcenie ${ }^{7}$.

Dla większej przejrzystości można wyróżnić chwałę Bożą:

- wewnętrzna, która polega na życiu wewnatrztrynitarnym Osób Bożych. Bóg Ojciec przez intelektualne zrodzenie Syna poczyna z Siebie Slowo, będące odbiciem Jego Samego, Jego życia, piękna i wszystkich nieskończonych doskonalości. We wzajemnej kontemplacji pomiędzy Ojcem i Syna utrwala się droga pochodzenia milość osobowa - Duch Święty. Taki rodzaj milości związany z poznaniem i „wzajemnym zachwytem” stanowi treść chwaly wewnętrznej, wiecznej i doskonalej, której żadne z inteligentnych stworzenie nie jest w stanie nigdy osiagnać;

- zewnętrzna, chodzi tutaj o to, iż Bóg doskonaly sam w sobie nie potrzebuje stworzeń dla swego uszczęśliwienia. Motywem stworzenia jest doskonała Boża Miłość, Dobro Najwyższe. Naturą miłości jest jej udzielanie się, dobro zaś dąży do rozprzestrzeniania się (bonum diffusivum est). Wszystkie stworzenia zatem istnieją w Bogu i dla Boga. Niemożliwym byloby to, aby Bóg stworzyl świat dla celu różnego od siebie samego, to znaczy celu zewnętrznego, któremu byłby podporządkowany. Wskazywało by to, że istnieje jakieś dobro poza Nim jeszcze nie osiagnięte, co zaprzeczaloby naturze Boga. $Z$ punktu widzenia stworzeń zewnętrzna chwała Boża jest rozumiana jako dążenie do najwyższej doskonałości, gdzie Bóg jest uwielbiony. Nie oznacza to transcendentnego egoizmu Boga. Uznanie absolutnej zależności od Boga i Jego doskonalości ma egzystencjalne, a nie tylko intelektualne, znaczenie dla stworzeń ${ }^{8}$.

${ }^{6}$ Tamże, s. $764-765$.

${ }^{7}$ J. A u m a n n: Teologia spirituale. Roma 1991 s. 41.

${ }^{8}$ W Konstytucji duszpasterskiej o Kościele w świecie współczesnym Gaudium et spes (n. 36) czytamy m.in.: Stworzenie bowiem bez Stworzyciela zanika. Zreszta wszyscy wierzacy, jakakolwiek wyznawaliby religie, zawsze w mowie stworzeń slyszeli glos i objawienie Stwórcy. Co więcej, samo stworzenie zapada w mroki przez zapomnienie o Bogu. 
Czlowiek dąży zatem do calkowitego podporządkowania się Stwórcy, aż odzyskawszy przez Chrystusa, z Chrystusem i w Chrystusie utracone w raju synostwo Boże, stanie się najdoskonalszym odbiciem harmonii Osób Boskich ${ }^{9}$.

Drugi cel życia duchowego, bliższy i względny to zbawienie jako życie w chwale. Cel ten ma charakter bardziej bezpośredni, dlatego też chrześcijanie są go bardziej świadomi, zwlaszcza w odniesieniu do zbawienia duszy. W związku z tym ma to większy wplyw na codzienne życie, niż myśl o chwale Bożej. Silna i wyraźna myśl o chwale Boże pojawia się bowiem dopiero na zaawansowanym etapie w osiaganiu doskonalości. Widać to zwlaszcza wtedy, kiedy rozważa trudności w pelnym podporząkowaniu się woli Bożej, jako owocu głębokiego i bolesnego oczyszczenia się z egoizmu. Zbawienie jednak jest ściśle związane z celem absolutnym: chwała Bożą, ponieważ ostateczne i doskonałe szczęście czlowieka w niebie będzie rezultatem pelni życia laski otrzymanej przez Chrystusa w Duchu Świętym. Tak wlaśnie pojęte życie jest uczestnictwem w życiu Trójcy Przenajświętszej (chwala wewnętrzna Boga) i źródłem usprawiedliwienia czlowieka oraz jego nadprzyrodzonej doskonalości (chwala zewnętrzna Boga).

Kwestia osiagnięcia szczęśliwości wiecznej nie może być pojęta w życiu ziemskim. Osiagnniecie jej zależy od calkowitej doskonalości danej jednostki ludzkiej i od poznania dobra w chwale ${ }^{10}$. Doskonalość ta weryfikuje się dopiero po śmierci.

W Katechizmie Kościoła Katolickiego (nr 313) czytamy o świadectwie świętych, którzy mówią o milości Boga skierowanej na zbawienie czlowieka.

Święta Katarzyna ze Sieny mówi więc do „tych”, którzy gorszą się i buntują przeciw temu, co im się zdarza: Wszystko pochodzi z milości, wszystko jest skierowane ku zbawieniu czlowieka, Bóg czyni wszystko tylko w tym celu ${ }^{11}$.

Święty Tomasz More przed swoim męczeństwem pociesza córkę: Nic nie może się zdarzyć, jeśli nie chcialby tego Bóg. A wszystko, czego On chce, chociaż mogloby wydawać się nam najgorsze, jest dla nas najlepsze ${ }^{12}$.

Warto dodać, iż w teologii mówi się o wizji uszczęśliwiającej polegającej na aktywności poznawania i milowania Absolutnego Dobra i Absolutnego Piękna. Będzie to partycypacja w chwale wewnętrznej Boga.

\footnotetext{
${ }^{9}$ J. B a u ma n n, dz. cyt., s. 41-44; A. R. Mar ti n: Teologia della perfezione. Milano 1987 s. $41-46$.

${ }^{10}$ Św. Tomasz z Akw in u, STH, I-II, q. 111, a.; q.114, a. $2-3$.

${ }^{11}$ Św. Katarzy na ze Sieny: Dialoghi, IV s. 138.

${ }^{12}$ Św. To m a s z Mor e: List do Alice Alington Margaret Roper, por. Liturgia godzin, III, z 22 czerwca
} 
Trzecim celem życia duchowego do którego zmierza rozwój duchowy jest uświęcenie i doskonalość. Kościól bowiem nieustannie uczy, iż wszyscy chrześcijanie jakiegokolwiek stanu i zawodu są powolani do pelni życia chrześcijańskiego i do doskonalej miłości ${ }^{13}$.

Uświęcenie rozumiane jako doskonałość życia duchowego wynika z samej natury życia. Każda bowiem istota żywa dąży do swego rozwoju i doskonalości. Miarą uświęcenia jest stopień uczestniczenia w świętości i doskonalości Boga mocą laski uświęcającej. Uświęcenie dla chrześcijanina oznacza upodobnienie się do Chrystusa (chrystomorfoza lub chrystyfikacja). Można przy tym rozróżnić dwa rodzaje świętości:

- świętość względna - charakterystyczna dla stanu życia ziemskiego, a zatem utracalna. Czlowiek, który jest w stanie laski uświęcającej, jest święty. Stąd też św. Pawel pisze do chrześcijan jako świętych ${ }^{14}$,

- świętość absolutna - wlaściwa dla stanu życia w niebie, a zatem nieutracalna, bo zjednoczeniu świętych z Bogiem w Chrystusie już nic nie zagra$\dot{z} \mathrm{a}^{15}$.

Reasumując należy powiedzieć, że dla chrześcijanina uświęcenie, a nawet doskonała szczęśliwość w niebie, nie stanowią ostatecznego celu rozwoju jego życia duchowego. Zbawienie i uświęcenie bowiem są wznioslymi, ale pośrednimi celami. Dzięki nim może być oddawana najdoskonalsza chwała Trójcy Przenajświętszej. W tym kontekście św. Jan od Krzyża pisal: Sama tylko chwała Boża i cześć mieszkają na tej górze ${ }^{16}$.

\section{Dialogiczne rozumienie rozwoju duchowego}

Dla lepszego zrozumienia rozwoju duchowego konieczne jest dokonanie analizy pojęcia dialogu duchowego, a następnie rozpatrzenie dialogu w odniesieniu do osobowego rozwoju.

\section{Pojęcie dialogu duchowego}

B. L. Sherwin w jednej ze swoich prac opisal wydarzenie, które może być równocześnie doskonalym wprowadzeniem do tej części wystapienia:

Pewien wielki rabin modlit się z takim zapatem, że zapomniał o własnym synu, którego przyprowadzil do synagogi. Chlopiec poczut się osamotniony, pociq-

${ }^{13}$ Sobór Watykański II: Konstytucja dogmatyczna o Kościele Lumen gentium, 40.

${ }^{14}$ Zob. Rz 15, 25-26.31; 16, 15-16; 1 Kor 16, 1; 2 Kor 1, 1; 13, 12; Ef 1, 1; 4, 12; 6, 18; Flp 1,$1 ; 4,21-22 ; \operatorname{Kol} 1,2 ; 1 \mathrm{Tm} 5,10$.

${ }^{15} \mathrm{~J}$. B a u m a n n, dz. cyt., s. 50-52.

${ }^{16}$ Św. Jan od Krzy ża: Dziela. Kraków 1986 s. 117. 
gnal ojca za plaszcz i zawolat: - Tato, tato! - Ojciec, wyrwany z rozmodlenia, zobaczyl smutek syna i sam się rozplakal. Dlaczego placzesz, tato? - zapytal chlopiec. - Dlatego - odpowiedziat rabin - że gdybym ja tak wolal Boga „, Ojcze, Ojcze", jak ty mnie wolateś, Bóg uslyszalby moje wolanie i objatby mnie tak, jak ja ciebie teraz trzymam ${ }^{17}$.

Ojciec dopiero wtedy mógł zrozumieć czym jest dialog. Prawdziwy dialog bowiem wyraża się w poszukiwaniu pelnej prawdy, bez ukrywania i upiększania czegokolwiek, tylko dialog zwiąany z calkowita otwartościa i chęcia zrozumienia partnera dialogu tak, jak sam siebie rozumie, może być dialogiem twórczym, shużącym duchowemu rozwojowi ${ }^{18}$. To intuicyjne, sapiencjalne rozumienie dialogu jest bliskie rozumieniu naukowemu. Dialog bowiem (grec. diálogos) można rozumieć jako:

- rozmowę dwu osób;

- rozmowę dwu lub więcej osób w utworze literackim; utwór literacki w formie rozmowy;

- rodzaj widowiska teatralnego w średniowiecznej Polsce ${ }^{19}$.

Istnieje też francuski zwrot dialogue des sourds, co oznaczałoby w dosłownym thumaczeniu rozmowę gluchych, dyskusję, której uczestnicy nie zwracaja uwagi na argumenty drugiej strony, (co można by zauważyć w niektórych debatach polityków $)^{20}$.

We wspólczesnej teologii dialog oznacza pewien typ rozmów między osobami o różnych przekonaniach, prowadzoną w celu osiagnięcia porozumienia albo przynajmniej zbliżenia poglądów. W dialogu chodzi także o wspóldziałanie w zakresie poszukiwania prawdy, stwarzanie podstaw wspólpracy dla obrony wartości ogólnoludzkich. W takim rozumieniu dialogu zakłada się u partnerów przekonanie o zasadniczo niepelnym uczestnictwie w prawdzie - takim, które może się doskonalić w wyniku poznania poglądów innych partnerów dialogu ${ }^{21}$. Znamienne w dialogu jest to, iż zaklada on uznanie godności oraz wolności każdego człowieka i jego prawa do wyrażania pogladów (nawet obiektywnie blędnych). Zakłada się przy tym istniejące na początku różnice w ujmowaniu zagadnień, polączoną jednak $z$ wolą zmniejszenia tych różnic. W takiej postawie kryje się przekonanie o jakiejś fundamentalnej jedności ludzkiego dążenia do prawdy

${ }^{17}$ B. L. S h e rw in: Wiara, duchowość i etyka spoleczna Żydów. We wspólpracy z Bogiem. Kraków 2005 s. 42.

${ }^{18}$ Tamże, H. Mu sz y ń sk i: Slowo wstęne, s. 8.

${ }^{19}$ J. To k a r s ki: Fleksja polska. Warszawa 1973 s. 151

${ }^{20}$ W. K o p a 1 ińs ki: Slownik wyrazów obcych $i$ zwrotów obcojęzycznych z almanachem. Warszawa 2000 s. 123.

${ }^{21}$ Tamże, s. 309. 
umożliwiające rozumiejące shuchanie i asymilację prawdy poznanej przez innych. Takiego rodzaju jedność poznania pozwala partnerom dialogu przekraczać granice wlasnych przekonań, nawet tak glęboko zakorzenionych i społecznie uwarunkowanych, jak przekonania światopogladowe czy religijne ${ }^{22}$.

W Katechizmie Kościola Katolickiego ${ }^{23}$ dialog rozumiany jest przede wszystkim jako rozmowa. Czlowiek bowiem tak zostal stworzony, że ma naturę „otwartą" na Boga (capax Dei). Poprzez dialog, rozumiany jako rozmowa potwierdza swoje naturalne pragnienie Boga. Bóg nie przestaje przyciagać czlowieka do siebie i tylko w Bogu czlowiek znajdzie prawdę i szczęście, których nieustannie szuka ${ }^{24}$.

Osobliwą rację godności ludzkiej stanowi powolanie czlowieka do uczestniczenia w życiu Boga. Człowiek już od swego początku zapraszany jest do rozmowy z Bogiem: istnieje bowiem tylko dlatego, że Bóg stworzyl go z milości i wciąż z milości zachowuje, a żyje w pelni prawdy, gdy dobrowolnie uznaje owa milość i powierza się swemu Stwórcy ${ }^{25}$.

Katechizm wspomina o znaczeniu dialogu w 11 punktach $^{26}$. Pojęcie to używane jest w różnych kontekstach, najczęściej odnoszących się do kwestii ekumenicznych. Termin dialog w odniesieniu do rozwoju duchowego najpelniej wyraża się w sakramentalnej celebracji.

Celebracja sakramentalna jest spotkaniem dzieci Bożych z Ojcem w Chrystusie i Duchu Swiętym; spotkanie to wyraża się jako dialog przez czynności i słowa. $Z$ pewnością same czynności symboliczne mają już jakaśs wymowę. Slowo Boże oraz odpowiedź wiary powinny jednak towarzyszyć im i ożywiać je, by ziarno Królestwa wydało owoc na dobrej ziemi. Czynności liturgiczne oznaczaja to, co wyraża slowo Boże: bezinteresowną inicjatywę Boga, a zarazem odpowiedź wiary Jego ludu ${ }^{27}$.

Dialog wlaściwie rozumiany wyraża wspólnotowy charakter powolania ludzkiego. Osoba ludzka potrzebuje życia spolecznego. Nie jest ono dla niej czymś dodanym, lecz jest wymaganiem jej natury. Przez wymianę z innymi, wzajemną shuzbę i dialog $\mathrm{z}$ braćmi czlowiek rozwija swoje możliwości; w ten

${ }^{22}$ Tamże, s. 309-310.

${ }^{23} \mathrm{KKK}, 27$.

${ }^{24}$ Tamże, 27.

${ }^{25}$ Sobór Watykański II: Konstytucja duszpasterska o Kościele w świecie współczesnym Gaudium et spes, 19.

${ }^{26}$ Zob. KKK, 27, 39, 821, 856, 1126, 1153, 1636, 1879, 2063, 2575, 2653.

${ }^{27} \mathrm{KKK}, 1153$ 
sposób odpowiada na swoje powolanie ${ }^{28}$. Wyrazem dialogu czlowieka z Bogiem jest modlitwa. Chodzi zwlaszcza o modlitwę wyrastającą ze źródel biblijnych. Kościól usilnie i szczególnie zachęca wszystkich wiernych ... by przez częste czytanie Pisma świętego nabywali wzniostego poznania Jezusa Chrystusa... Czytaniu Pisma Świętego powinna towarzyszyć modlitwa, by nawiazywata się rozmowa między Bogiem a czlowiekiem, gdyż do Niego zwracamy się, gdy się modlimy, to Jego shuchamy, gdy czytamy Boskie wypowiedzi ${ }^{29}$.

Istota Boga przekracza naszą wiedzę i doświadczenie. Pewien średniowieczny filozof żydowski twierdził, że gdybyśmy zrozumieli Boga, wtedy bylibyśmy Bogiem. Naszym zadaniem nie jest zrozumienie Boga, lecz stanie się świadkiem Jego obecności w świecie. Nasz stosunek do Boga jest określony przez przymierze z Nim. Jak każde przymierze, jak każda umowa, przymierze z Bogiem to wspóldzialanie $^{30}$. Można w tym kontekście powiedzieć, że dialog to podstawowy sposób nawiązywania kontaktu z Bogiem.

\section{Dialog a rozwój osobowy}

Dialog jest bez watpienia jednym $z$ podstawowych wyznaczników rozwoju osobowego. Jednakże przy próbie holistycznego ujęcia dialogu w kontekście rozwojowym należałoby uwzględnić zmienną wieku osoby. Znanym jest jednak fakt, że dialog pojawia się w rozwoju osoby w procesie socjalizacji ${ }^{31}$. Socjalizację można by określić jako proces oddzialywania grupy ludzi na jednostkę. W szerszym znaczeniu tego terminu wszelkie oddzialywanie grupy na jednostke należy określić mianem socjalizacji. W ujęciu węższym zaś mamy do czynienia z socjalizacją w sytuacji oddzialywania na jednostkę grupy reprezentującej określoną kulturę, religię czy wyznanie, powodującej wystapienie społecznie pożądanych zmian w zachowaniu się tej osoby ${ }^{32}$. Warto zwrócić przy tym uwage na zakres pojęcia socjalizacji w przedstawiony w poniższej tabeli.

\begin{tabular}{|l|l|l|}
\hline \multicolumn{1}{|c|}{$\begin{array}{c}\text { Kryteria określenia zakresu } \\
\text { pojęcia socjalizacji }\end{array}$} & $\begin{array}{c}\text { Szerszy zakres pojęcia socja- } \\
\text { lizacji }\end{array}$ & $\begin{array}{c}\text { Węższy zakres pojęcia } \\
\text { socjalizacji }\end{array}$ \\
\hline $\begin{array}{l}\text { Rodzaj grup oddziałujacych na } \\
\text { jednostkę }\end{array}$ & $\begin{array}{l}\text { Grupy tworzace zarówno } \\
\text { kulturę, jak i podkulturę }\end{array}$ & Grupy tworzące kulturę \\
\hline $\begin{array}{l}\text { Zmiany zachodzace w jednostce } \\
\text { pod wpływem oddzialywania } \\
\text { grupy }\end{array}$ & $\begin{array}{l}\text { Wszelkie zmiany dokonujące } \\
\text { się w jednostce }\end{array}$ & $\begin{array}{l}\text { Zmiany w zakresie czyn- } \\
\text { ności społecznych poży- } \\
\text { teczne dla grupy }\end{array}$ \\
\hline $\begin{array}{l}\text { Okres życia, w którym zachodzi } \\
\text { socjalizacja }\end{array}$ & $\begin{array}{l}\text { Socjalizacja zachodzi w róż- } \\
\text { nych okresach życia }\end{array}$ & $\begin{array}{l}\text { Socjalizacja dokonuje już } \\
\text { się w okresie dzieciństwa }\end{array}$ \\
\hline
\end{tabular}

${ }^{28}$ Gaudium et spes, 25.

${ }^{29} \mathrm{KKK}, 2653$

${ }^{30}$ A. J. He s c h e l: Man is not alone. Philadelphia 1951 s. 242-244.

${ }^{31}$ D. W o o d: How children think and learn. The social context of cognitive development. Malden 1998 s. 23-31.

${ }^{32}$ Z. S k o r n y: Proces socjalizacji dzieci i mlodzieży. Warszawa 1987 s. 10-12. 
Nie można jednak w holistycznym pojmowaniu rozwoju osobowego pomijać socjalizacji religijnej. Socjalizacja religijna wiąże się z nabywaniem zespolu trwalych cech, majacych wplyw na postępowanie religijne. Jest ona procesem wychowawczym, rozumianym jako dialogiczny proces, którego celem jest wyksztalcenie w jednostce postaw szacunku wobec tego, co transcendentne ${ }^{33}$. Socjalizować religijnie to przede wszystkim przysposabiać poprzez dialog, do internalizacji przez osobę określonych wartości i norm religijno-moralnych, uznawanych w danej spoleczności konfesyjnej jako obowiazujące i sankcjonowane, a także jest to proces uczenia się i przygotowywania do pelnienia przyszlych ról religijnych $^{34}$. Socjalizacja religijna dokonuje się także poprzez przekazywanie $z$ pokolenia na pokolenie kulturowego dziedzictwa religijnego, tj. modeli zachowań religijnych, związanych $\mathrm{z}$ wiedzą religijna, wierzeniami religijnymi, praktykami religijnymi, zwyczajami i obyczajami, oraz na przystosowaniu do tych modeli zachowań religijnych ${ }^{35}$. W innym rozumieniu socjalizacja religijna jest pojmowana jako uczenie się konformizmu wobec zastanego systemu aksjologicznonormatywnego, w tym również religijnego. Takie rozumienie socjalizacji religijnej dotyczy zwlaszcza mlodego pokolenia, które ulega wymogom i oczekiwaniom kręgów wychowawczych, pozostając równocześnie pod wpływem innych grup odniesienia ${ }^{36}$.

Wspólcześni badacze zjawiska socjalizacji religijnej w Polsce wskazują na jej kryzys i wyodrębniaja czynniki odpowiedzialne za taka sytuację:

- transformacja społeczno-kulturowa wspólczesnych społeczeństw, przejawiajaca się w przechodzeniu od spoleczeństwa typu tradycyjnego do pluralistycznego;

- spadek, w porównaniu z rodzicami, dynamiki religijności u dzieci, będący skutkiem odchodzenia od tradycyjnego modelu religijności do modelu religijności z wyboru (przeprowadzane badania socjologiczne pokazuja zależność między religijnością rodziców a ich dzieci);

- rozluźnienie więzi młodego pokolenia z parafią wskutek przeniesienia katechezy z sal przyparafialnych do szkól;

- tendencja do samostanowienia w dziedzinie wiary, norm moralnych i zaangażowania kultycznego;

- przerzucanie odpowiedzialności za edukację religijną na Kościól i katechezę szkolna;

\footnotetext{
${ }^{33}$ Por. W. P i w o w a r s k i: Socjologia religii. Lublin 1996.

${ }^{34}$ S.H. Zar ę ba: Socjalizacja religijna. W: M. L i b i szowska-Ż́łłtkowska, J. $\mathrm{M}$ a r i án s k i: Leksykon socjologii religii, dz. cyt., s. 370.

${ }^{35}$ Por. W. Pi w o war s ki, dz. cyt.

${ }^{36}$ S.H. Z a rę b a, dz. cyt., s. 370.
} 
- wplyw kultury masowej, propagujacej postawy liberalne, relatywistyczne, indywidualistyczne i subiektywistyczne;

- spadek sily oddzialywania instytucji dotychczas odpowiedzialnych za socjalizacje religijną (rodzina, Kościól, szkolna katecheza ) ${ }^{37}$.

Współczesny dialog chrześcijanina z Bogiem rozgrywa się na plaszczyźnie doczesnego zaangażowania, które plynie z przekonania o wartości spraw doczesnych. Ludzkie życie i zdrowie somatyczne i psychiczne, wszechstronny rozwój czlowieka, wszystko od najbardziej codziennych, znikomych spraw do niezwyklych, brzemiennych w skutki ludzkich osiagnięć, posiada autentyczna wartość, której lekceważenie oznaczałoby lekceważenie Boga - Stwórcy i Zbawiciela świata i czlowieka ${ }^{38}$. Stąd też wiara $\mathrm{w}$ zmartwychwstanie i życie wieczne nie tylko nie stoi na przeszkodzie w podejmowaniu dialogu i twórczemu zaangażowaniu w budowaniu lepszego świata, ale wymaga takiego zaangażowania. Niechże się więc nie przeciwstawia sobie blędnie czynnosici zawodowych i społecznych z jednej strony, a życia religijnego z drugiej strony [... ]. Chrześcijanin zaniedbujący swoje obowiqzki wobec bliźniego, co więcej, wobec samego Boga, naraża na niebezpieczeństwo swoje wieczne zbawienie ${ }^{39}$.

Cz. S. Bartnik uważa, że dla zbawienia konieczny jest osobowy dialog. Nie ma bowiem zbawienia bez osób. Można nawet postawić bardzo śmiałą tezę, że gdyby Bóg byl w jednej osobie, to nie byloby miejsca dla zbawienia ludzi, bo nie byłoby prapierwotnego wzorca zbawienia jako komunii osoby z osoba; gdyby nie bylo Trójcy Świętej, nie byloby zbawienia osób ludzkich ${ }^{40}$.

Wydaje się, że największym przymiotem Trójcy Świętej jest możność tworzenia przez nią osób. Tworzenie to zaś jest niejako potrójne: stwarzające osobę w naturze, zbawiające osobę w historii i spelniające osobę na lonie Trójcy. Są to jakby trzy stwarzania osób. We wszystkich tych aktach, jakby sukcesywnie otwierają się czlowiekowi osobny Boskie jako osoby, jakby staja mu się osoba$\mathrm{mi}^{41}$.

Zbawienie jest procesem osobowym, wbrew temu czego uczyla dawna teologia, która traktowała zbawienie nieco reistycznie, jako sytuację, stan nasycenia dobrami, obawiajac się przy tym akcentowania roli osoby jako rzekomo prowadzącego do subiektywizacji zbawienia.

${ }^{37}$ Tamże, s. 373.

${ }^{38}$ A. Z u ber bi er: Wierzę. Katowice 1979 s. 314-315.

${ }^{39}$ Gaudium et spes, 43.

${ }^{40} \mathrm{Cz}$. S. B a rtn i k: Medytacja personalistyczna o zbawieniu. W: Teologiczne rozumienie zbawienia. Red. Cz. S. B a r tn i k. Lublin 1979 s. 185.

${ }^{41}$ Tamże, s. 185. 
Tymczasem podmiotowość zbawienia, jego „osobowość" nie utożsamia się z nierzeczywistością czy pozornością. Zbawienie w osobie jest bardziej „realne” niż w rzeczach. Stąd i pewne formy oraz prawa zbawienia są regulowane przez akty osobowe na inny sposób niż dzialanie zewnętrzne. Tutaj nabiera szczególnej wagi afirmacja lub negacja Chrystusa, czyn moralny lub grzeszny, przyjęcie nieśmiertelności lub jej odrzucenie. Przede wszystkim decyduje personalne wlączenie się czlowieka w zbawienie ofiarowywane przez Boga. W ten sposób zbawienie jest związaniem w calość rzeczywistości zewnętrznej i wewnętrznej, przedmiotowej i podmiotowej, osobowej i nieosobowej. To samo odnosi się i do zbawienia jako idacego od Boga, jako dzialania Bożego oraz jako respondujacego ze strony czlowieka; jedno i drugie tworzy nierozerwalną całośćc ${ }^{42}$.

\section{Rozwój duchowości katolickiej w nauczaniu Jana Pawła II}

Jan Pawel II w liście apostolskim Novo millennio ineunte ${ }^{43}$ napisal, iż: współcześnie obserwuje się powszechnq potrzebę duchowości, która w znacznej mierze ujawnia się właśnie jako nowy glód modlitwy. Także inne religie, obecne już na szerokq skalę również na terenach od dawna schrystianizowanych, proponuja wlasne sposoby zaspokojenia tej potrzeby i czyniq to czasem w sposób bardzo przekonujacy. My jednak, skoro zostala nam dana laska wiary w Chrystusa, który objawia Ojca i jest Zbawicielem świata, mamy obowiazek ukazywać, na jakq glębię może nas doprowadzić więź z Nim. Wyraźne zainteresowanie duchowością a może raczej powrót do zagadnień zwiazanych $z$ duchowością, po latach ciężkich doświadczeń początku XX wieku sprawil, iż Sobór Watykański II podją problematykę duchowości. Odnowa soborowa w dziedzinie duchowości zaznacza się przede wszystkim podkreśleniem centralnej roli misterium zbawczego Jezusa Chrystusa, powszechności powołania do świętości w Kościele ${ }^{44}$, zakorzenieniem w Piśmie Świętym, Tradycji i liturgii, otwarciem na świat współczesny (aggiornamento i ,znaki czasu”) oraz zwróceniem uwagi na podmiotowość czlowieka (tzw. „zwrot antropologiczny"). Wobec tego duchowość posoborowa można by określić jako chrystologiczno-inkarnacyjna, biblijno-liturgiczną i eklezjalno-personalistyczna. W tym wszystkim dostrzega się nieodzowna rolę Ducha Swiętego ${ }^{45}$.

\section{Duchowość laikatu}

Jan Paweł II ogromną rolę w odpowiedzialności za duchowy wymiar Kościola przypisuje ludziom świeckich. $\mathrm{W}$ tym też kontekście naucza: Zrzeszanie się

\footnotetext{
${ }^{42}$ Tamże, s. 186.

${ }^{43}$ J a n P a w e 1 II: List apostolski Novo millennio ineunte, 33.

${ }^{44}$ Sobór Watykański II: Konstytucja dogmatyczna o Kościele Lumen gentium, 39.

${ }^{45}$ M. C h m i e l e w s k i: Vademecum duchowości katolickiej. Lublin 2004 s. 36-37.
} 
świeckich $w$ celu realizowania zadan duchowych $i$ apostolskich posiada wiele motywów i jest odpowiedziq na wiele zapotrzebowan. Wyraża się w tym bowiem spoleczna natura czlowieka oraz realizuje potrzeba poszerzenia zakresu i skuteczności jego dziatań. W rzeczywistości wplyw ,kulturowy”, będqc źródlem $i$ bodźcem, ale także owocem $i$ znakiem wszelkich innych przemian w środowisku $i$ spoleczeństwie, może zaistnieć tylko dzięki dzialaniu nie tyle jednostek, co ,,podmiotu spolecznego", to jest jakiejś grupy, wspólnoty, zrzeszenia bądz ruchu. Znajduje to szczególne potwierdzenie w obrębie spoleczeństwa pluralistycznego $i$ rozczlonkowanego - z jakim stykamy się obecnie na calym świecie - oraz w sytuacjach szczególnie zlożonych i trudnych. $Z$ drugiej strony, rozmaite formy zrzeszonej dzialalności świeckich, wlaśnie $w$ świecie zsekularyzowanym, stanowiq wyjatkowo cenna pomoc dla wielu ludzi w prowadzeniu chrześcijańskiego życia zgodnego $z$ wymaganiami Ewangelii oraz $w$ zaangażowaniu misyjnym $i$ apostolskim $^{46}$. Istotne jest przy tym to, iż Ojciec Święty przelamuje dawne stereotypy na temat miejsca i odpowiedzialności świeckich za Kościół. W posynodalnej adhortacji apostolskiej Christifideles laici, wychodzac od biblijnego obrazu winnego krzewu, z którego winorośle czerpią ożywcze soki, papież stwierdza, że tylko w tajemnicy Kościola, jako tajemnicy komunii, objawia się tożsamość świeckich, ich autentyczna godnośc ${ }^{47}$. Dlatego też wzywa wszystkich świeckich, aby coraz wyraźniej uświadamiali sobie, iż nie tylko, że należq do Kościola, ale że sami sq Kościolem $^{48}$. Przez chrzest święty zostali wszczepieni w Chrystusa, a tym samym w Jego Mistyczne Ciało - Kościól święty, co jeszcze wyraźniej potwierdza przyjęty sakrament bierzmowania. Są więc rzeczywiście żywymi latoroślami Chrystusa. Toteż każdy świecki przez chrzest święty dostępuje godności dziecka Bożego i na mocy tej godności jest współodpowiedzialny, wraz z kaplanami, zakonnikami i zakonnicami, za misję Kościola ${ }^{49}$. Z tego wlaśnie powodu, Kościól posiada autentyczny wymiar świecki, ściśle związany z jego naturą i misja.

Można zatem powiedzieć, że Kościól nie tworzyłby pelnej calości bez wiernych świeckich. To nie jest Kościól tylko duchownych i zakonników. Gdyby w Kościele zabraklo świeckich, wówczas duchowni i osoby konsekrowane utracilyby wlasną tożsamość. Zamiast więc w duchu dawnych stereotypów sztucznie przeciwstawiać sobie poszczególne stany w Kościele, należy koniecznie podkreślać ich komplementarność. Pod tym względem Kościól święty można porównać do trójnożnego stolika, który tylko wówczas jest użytecznym meblem, gdy stoi równo na wszystkich nogach. W przeciwnym razie może służyć jedynie za szacowny zabytek ${ }^{50}$.

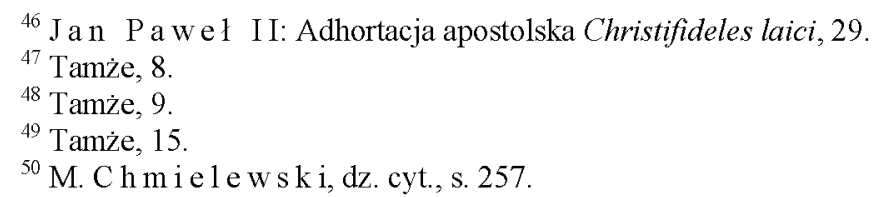


Podstawa duchowości ludzi świeckich jest więc chrzest święty, zakorzeniający ich w Chrystusie i Kościele, jak również świeckość, jako dane im przez Stwórcę zadanie czynienia sobie ziemi poddanq ${ }^{51}$. Zwyczajnym powolaniem świeckich katolików jest malżeństwo, w konsekwencji tego życie rodzinne. Stąd też można mówić o specyficznej duchowości malżeńsko-rodzinnej, u podstaw której jest sakrament malżeństwa. Jan Pawel II w adhortacji apostolskiej o zadaniach rodziny chrześcijańskiej w świecie wspólczesnym Familiaris consortio uczy, że wlaściwym źródlem i pierwotnym środkiem uświęcenia malżeństwa $i$ rodziny chrześcijanskiej jest sakrament malzeństwa, który podejmuje i rozwija laskę uświęcajaca chrztu ${ }^{52}$. Jeżeli przez duchowość katolicką rozumiemy wspólpracę z Duchem Świętym w dziele naszego uświęcenia i zbawienia, to w malżeństwie, w odróżnieniu od innych stylów życia w Kościele, dokonuje się ona w ścisłym odniesieniu do drugiej osoby zaślubionej w sposób sakramentalny. W pierwszej swej encyklice Redemptor hominis Papież pisze, że: czlowiek jest droga Kościola ${ }^{53}$. Wydaje się, że ta prawda nabiera sensu szczególnie w odniesieniu do malżeństwa i rodziny, która już Ojcowie Kościoła nazywali domowym Kosciolem (ecclesiola).

W malżeństwie droga do Boga - droga osobistego uświęcenia, wpisuje się w życie wspólmalżonka, dzieci i najbliższej rodziny. Ta wspólodpowiedzialność za życie duchowe w malżeństwie i rodzinie idzie tak daleko, że można wprost powiedzieć, iż nikt $z$ małżonków nie uświęca się i zbawia sam, a także nie potępia się sam, zawsze bowiem pociąga za sobą wspólmałżonka i dzieci: ku świętości albo ku potępieniu ${ }^{54}$.

Jan Pawel II wyraźnie podkreśla specyfikę duchowości małżeńsko-rodzinnej, pisząc: Powszechne powolanie do świętości jest skierowane również do malżonków i rodziców chrześcijańskich: określone w sprawowanym sakramencie zostaje przelożone na konkretny język rzeczywistości życia matżeńskiego i rodzinnego. Stąd też rodzi się laska i wymóg autentycznej i glębokiej duchowości malżeńskiej i rodzinnej, która będzie czerpala natchnienie z motywów stworzenia, przymierza Krzyża i zmartwychwstania ${ }^{55}$.

Papież w innym miejscu podkreśla, iż rodzina jest centrum $i$ sercem cywilizacji milości $i^{56}$. Chodzi o to, aby chrześcijańscy małżonkowie oraz ich rodzina, żyjąc glębokim zjednoczeniem z Bogiem-Miłością, starali się w otaczającej ich rzeczywistości wprowadzać zasady wynikające z przykazania milości i szacunku

\footnotetext{
${ }^{51}$ Por. Rdz 1, 28.

${ }^{52} \mathrm{~J}$ a n $\mathrm{P}$ a w e 1 I I: Adhortacja apostolska Familiaris consortio, 56.

${ }^{53} \mathrm{~J}$ an $\mathrm{P}$ aw e 1 II: Encyklika Redemptor hominis, 14.

${ }^{54}$ M. Chmi el ew ski, dz. cyt., s. 267.

${ }^{55} \mathrm{~J}$ a $\mathrm{P}$ P a w e 1 I I: Adhortacja apostolska Familiaris consortio, 56.

${ }^{56}$ J a n P a w e 1 II: List do Rodzin Gratissimam sane z okazji Roku Rodziny (2.02.1994).
} 
dla czlowieka. Warto dodać, iż Ojciec Święty wyraźnie dostrzegal niezwykle cenny wklad ludzi starszych i cierpiących w życie duchowe Kościola i wlasnych rodzin. Moga oni, a nawet powinni ofiarować bezcenny dar swego cierpienia związanego z ograniczeniami trzeciego wieku. Cierpienie nie tylko ma slużyć nawróceniu, czyli odbudowaniu dobra w podmiocie, który w wezwaniu do pokuty może rozpoznać Miłosierdzie Boże ${ }^{57}$, ale także jest wezwaniem do ujawnienia moralnej wielkości czlowieka, jego duchowej dojrzalości ${ }^{58}$. Zatem czlowiek starszy, samotny i cierpiący może swoje wielorakie cierpienie potraktować nie tylko jako wynagrodzenie (ekspiację) za wlasne grzechy, ale uczynić je charyzmatem darem dla innych, aktem wstawienniczym, szczególnie za czlonków najbliższej rodziny.

Świadomość nadchodzącego kresu życia sprawia, że osoby starsze mają specyficzne poczucie czasu i wartości doczesnego świata. Na ogól nie jest ono znane ludziom mlodym i dynamicznym, gdyż ma coś z przedsmaku wieczności. Dzielenie się tym doświadczeniem o charakterze eschatologicznym jest z pewnościa cennym wkladem w życie duchowe rodziny i najbliższego środowiska, uświadamia bowiem, że lata nasze przemijają i nie mamy tutaj trwałego miasta, ale szukamy tego, które ma przyjśśc ${ }^{59}$.

\section{Duchowość kaplańska}

Istotnym rysem duchowości kaplańskiej jest milość pasterska. W tym kontekście Jan Pawel II twierdzil, iż kaplan musi być świadomy, że jego bycie w Kościele lokalnym stanowi, ze swej natury, element pozwalający żyć duchowością chrześcijańską ${ }^{60}$. Ma on być promotorem życia duchowego nie tylko ze względu na siebie, co przede wszystkim ze względu na wiernych. Dlatego troska o życie duchowe powinna być odczuwana jako radosny obowiązek ze strony samego kaplana, ale także jako prawo wiernych, którzy szukają w nim, świadomie czy nieświadomie, czlowieka Bożego ${ }^{61}$. Wlaśnie w trosce o życie duchowe najpelniej wyraża się milość pasterska kaplanów, wzorowana na postawie Chrystusa Dobrego Pasterza ${ }^{62}$.

Miłość pasterska kaplana w zakresie funkcji uświęcania (kaplańskiej) wyrażać się będzie przede wszystkim w poprawnym i zaangażowanym celebrowaniu Eucharystii, jest ona bowiem zasadniczą racją sakramentu kaplaństwa.

\footnotetext{
${ }^{57}$ J an P aw e 1 I I: List apostolski Salivifici doloris, 12.

58 Tamże, 22

${ }^{59}$ Por. Ps 37,2 ; Hbr 13, 14.

${ }^{60}$ J an Pawe 1 II: Adhortacja apostolska Pastores dabo vobis o formacji kaplanów we współczesnym świecie, 31.

${ }^{61}$ Kongregacja do spraw Duchowieństwa: Dyrektorium o posludze i życiu kaplanów, 39.

${ }^{62}$ Por. J $10,1-18$.
} 
W zakresie funkcji prorockiej kaplan swoją milość pasterską okazuje poprzez wielkodusznie podejmowany trud katechezy i kaznodziejstwa. Warto w tym miejscu przytoczyć wypowiedź Kongregacji do spraw Duchowieństwa: Trzeba rozwijać prawdziwa , oświecona milość” poprzez stała i cierpliwie przekazywanq katechezę, osnutq wokót podstawowych prawd katolickiej wiary i moralności, które ksztaltuja życie duchowe. Chrześcijańskie nauczanie należy do szczytowych form duchowego milosierdzia ${ }^{63}$.

Najbardziej widocznym przejawem milości pasterskiej kaplana jest pelniona przez niego posluga kierowania i administrowania wspólnotą oraz należącymi do niej dobrami materialnymi (funkcja królewska). W centrum tej poslugi jest szeroko rozumiana dzialalność charytatywna, a także wychowawcza. Również troska o bezpieczeństwo i estetykę światyni, jej wyposażenie, archiwum parafialne itp., czyż nie jest wyrazem milości do ludzi, którzy tworzą daną wspólnotę parafialną? Nie można zapominać, że milość pasterska kaplana zobowiązuje go do synowskiej więzi ze swoim biskupem, któremu w chwilach swoich święceń składal ślub czci i posłuszeństwa. Tym samym każdy kapłan zobowiazany jest do zachowania jedności z innymi kapłanami, czyli z tzw. prezbiterium diecezjalnym. Warto podkreślić to, że kaplan nawet nie zatrudniony bezpośrednio $\mathrm{w}$ pracy duszpasterskiej, pielęgnuje milość pasterska, może być pewny, że zawsze doświadczy milości odwzajemnionej: od Chrystusa i od ludzi ${ }^{64}$. Swoistą syntezę nauki a temat duchowości kaplańskiej zarysowal Jan Pawel II w homilii wygloszonej 9 października 1984 roku do kaplanów biorących udział w międzynarodowych rekolekcjach: Powolanie kaplańskie jest zasadniczo wezwaniem do świętości w tej formie, która wyplywa z sakramentu kaplaństwa. Świętość jest zażyłościq z Bogiem, jest naśladowaniem Chrystusa ubogiego, czystego i pokornego, jest bezgranicznym umilowaniem ludzi i oddaniem się ich prawdziwemu dobru; jest milościq Kościola, który jest święty i pragnie, byśmy i my byli święci, bo taka jest misja, jakq powierzyt mu Chrystus. Każdy z was musi być święty, by pomagać także braciom $w$ realizowaniu ich powolania do świętości.

W. Słomka uważa, iż najbardziej istotne dla kaplanów w pojmowaniu kaplaństwa $\mathrm{i}$ jego duchowości, jest zrozumienie, że Jedynym kaplanem Nowego Przymierza jest sam Jezus Chrystus, a kaplani moca sakramentu święceń, staja się uczestnikami kaplaństwa poprzez otrzymaną zdolność bycia i pełnienia Chrystusowego posłannictwa in persona Christi Capitis et Pastoris Ecclesiae - w Osobie Chrystusa Glowy i Pasterza ${ }^{65}$.

${ }^{63}$ Kongregacja do spraw Duchowieństwa: Kaplan glosiciel slowa, szafarz sakramentów $i$ przewodnik wspólnoty $w$ drodze do trzeciego tysiąclecia chrześcijaństwa, II, 2.

${ }^{64} \mathrm{M} . \mathrm{C}$ h m i e l e w s k i, dz. cyt., s. 240.

${ }^{65}$ W. Sło m k a: Duchowaść kaplańska. Lublin 1996 s. 296. 


\section{Duchowość życia konsekrowanego}

Podjęcie drogi życia konsekrowanego dokonuje się przez profesję rad ewangelicznych, zwaną potocznie skladaniem ślubów lub innej formy publicznego zobowiązania się do: czystości, ubóstwa i poshuszeństwa. Te trzy śluby streszczaja zawarte w Ewangelii rady i zachęty Chrystusa do życia doskonalego. Sa one przeciwieństwem trzech głównych pożądliwości, a mianowicie pożąliwości oczu, ciala i pysze. W tym kontekście Jan Pawel II pisze, że czystość w sposób szczególny zaadresowana jest do miłości serca ludzkiego. Uwydatnia ona bardziej rys oblubieńczy tej milości, podczas gdy ubóstwo, a zwlaszcza poshuszeństwo, zdają się uwydatniać przede wszystkim rys odkupieńczy milości zawartej w zakonnej konsekracji ${ }^{66}$.Specyfiką duchowości zakonnej jest realizowanie ślubów nie prywatnie, ale we wspólnocie. Stąd tak istotne znaczenie ma wymiar wspólnotowy duchowości zakonnej, będący odzwierciedleniem Kościola świętego, który z istoty swej jest wspólnota.

W adhortacji Vita consecrata Jan Paweł II zwraca uwagę na to, że czystość jako wyraz oddania się Bogu niepodzielnym sercem, jest odblaskiem nieskończonej miłości lqczqcej trzy Boskie osoby w tajemniczej glębi życia trynitarnego ${ }^{67} \mathrm{i}$ pozwala zarazem uczestniczyć w tym Boskim życiu przez kontemplację. W tym samym dokumencie Ojciec Święty dodaje: Ubóstwo glosi, że Bóg jest jedynym prawdziwym bogactwem czlowieka ${ }^{68}$, dlatego ślub ewangelicznego ubóstwa na wzór Chrystusa wyzwala czlowieka od skłonności konsumistycznych, a przez to czyni go bardziej wolnym do spelniania siebie w dawaniu siebie, tego kim się jest i co się posiada.

Istotą ślubu posłuszeństwa jest to, iż osoby konsekrowane poświęcają Bogu calkowicie swoja wolę, jakby skladając ofiare z siebie, a przez to jednoczą się trwalej i bezpieczniej ze zbawczą wola Boga ${ }^{69}$. Nawiązujac do tego Jan Pawel II uczy: Posluszeństwo praktykowane na wzór Chrystusa, którego pokarmem bylo wypetnianie woli Ojca, objawia wyzwalające piękno uleglości synowskiej, a nie niewolniczej, wzbogacanej poczuciem odpowiedzialności i przenikniętej wzajemnym zaufaniem: to zaufanie jest doczesnym odblaskiem harmonii milości, wlaściwej trzem Boskim Osobom ${ }^{70}$.

\footnotetext{
${ }^{66}$ J a n P a we 1 I I: Adhortacja apostolska Redemptionis donum o konsekracji zakonnej w świetle Odkupienia (25.03.1984).

${ }^{67} \mathrm{~J}$ a n P a w e 1 II: Adhortacja apostolska Vita consecrata, 21.

${ }^{68}$ Vita consecrata, 21

${ }^{69}$ Sobór Watykański II: Dekret o przystosowanej odnowie życia zakonnego Perfectae caritatis $(28.10 .1965), 14$

${ }^{70}$ Vita consecrata, 21
} 
W tym kontekście warto podkreślić, iż Duch Święty powolanych na drogę wspomnianych wyżej rad ewangelicznych nie odrywa od historii. W dziejach Kościola ksztaltowaly się różne formy życia konsekrowanego, i nadal pojawiaja się nowe ${ }^{71}$. Adhortacja Jana Pawla II Vita consecrata, poza najstarszymi formami (dziewice, wdowy, pustelnicy), rozróżnia: instytuty zakonne oddane calkowicie kontemplacji; instytuty oddane dziełom apostolskim, instytuty świeckie i stowarzyszenia życia apostolskiego. Wszystkie te formy życia obecnie egzystuja duchem wskazań soborowych, do których należy zaliczyć: prymat Ewangelii, partycypację w życiu Kościola, powrót do ducha założyciela ${ }^{72}$.

Oto sens powolania dożycia konsekrowanego: jest ono wyłączna inicjatywa Boga (por. J 15, 16), który oczekuje od tych, których wybral, odpowiedzi w postaci calkowitego i wylącznego oddania się Jemu. Doświadczenie tej bezinteresownej milości Boga jest tak glębokie i silne, że czlowiek czuje się zobowiązany odpowiedzieć na nie bezwarunkowym poświęceniem Mu wlasnego życia, zlożeniem w ofierze wszystkiego - teraźniejszości i przyszlości w Jego ręce ${ }^{73}$.

Uzasadniajac przesłanie i cel adhortacji Vita consecrata, Jan Pawel II pisze: Lata odnowy byly dla życia konsekrowanego, podobnie jak dla innych form życia w Kościele, okresem delikatnym i nielatwym. Byl to okres pelen nadziei, bogaty w próby i propozycje nowatorskie, majace ożywić praktykę rad ewangelicznych. Ale w okresie tym występowaly także napięcia i trudności, tak że nawet bardzo wielkoduszne inicjatywy nie zawsze przynosily pozytywne rezultaty.

Trudności nie powinny jednak zniechęcać. Należy raczej zdobyć się na nowy wysilek, ponieważ Kościól potrzebuje duchowego i apostolskiego wkladu, jaki może wnieść odnowione i pelne świeżych energii życie konsekrowane. W niniejszej Adhortacji posynodalnej pragnę zwrócić się do wspólnot zakonnych i do osób konsekrowanych $w$ tym samym duchu, jaki przenikal list skierowany przez Sobór Jerozolimski do chrześcijan w Antiochii; żywię przy tym nadzieję, że i ona zostanie dziś przyjęta w taki sam sposób [...] Więcej: mam również nadzieję, że uda mi się przysporzyć radości całemu Ludowi Bożemu, który poznawszy lepiej życie konsekrowane będzie mógl bardziej świadomie dziękować Wszechmogacemu za ten wielki dar ${ }^{74}$.

Na zakończenie warto dodać, iż Jan Pawel II zobowiąuje osoby konsekrowane do podejmowania dialogu milości ze światem, zwlaszcza tam, gdzie tocza się konflikty etniczne i szerzy się przemoc. Taki dialog i taka komunia bowiem

${ }^{71}$ T. P a sz k o w s k a: Misterium konsekracji osób w perspektywie duchowości Soboru Watykańskiego II. Lublin 2005 s. 204.

${ }^{72}$ Tamże, s. 204.

${ }^{73}$ Vita consecrata, 17

${ }^{74}$ Vita consecrata, 13 
jest zdolna polączyć w harmonijna calość wszelkie odmienności ${ }^{75}$. W tym wlaśnie kontekście sama ludzkość współczesna ze swoimi oczekiwaniami i zludzeniami staje się częścią konstytutywną teologii życia konsekrowanego, o ile tylko chce być ona autentyczna i wiarygodna ${ }^{76}$. Takie rozumienie duchowości życia konsekrowanego powoduje podwyższenie świadomości nie tylko u osób konsekrowanych, ale także u osób świeckich.

Jan Pawel II w czasie swojego pontyfikatu wielokrotnie okazywal zainteresowanie i pasterską troskę zagadnieniom związanych z duchowością katolicką. Warto przy tym podkreślić, iż rozwój duchowy jest na szczycie hierarchii rozwoju osobowego. Ojciec Święty w swoim nauczaniu zachęcal wiernych do podjęcia trudu glębokiej formacji duchowej, widzial jednocześnie zagrożenia i kryzysy duchowości we współczesnym Kościele. Efekty wspólpracy z laską Bożą są uwarunkowane przyczynami obiektywnymi i subiektywnymi. Te ostatnie zależą od takich dzialań, za które osoba ponosi odpowiedzialność. Chodzi zatem o nawrócenie, pragnienie doskonalości, życie sakramentalno-modlitewne, ascezę i podjęcie walki duchowej oraz zaangażowanie apostolskie. Glównym celem rozwoju duchowego jest oddawanie chwaly Bogu, a przy tym osiagnięcie zbawienia i uświęcenia. Ważkim zagadnieniem jest podjęcie kwestii dialogicznego rozumienia rozwoju duchowego. Wiąże się to jednak z problemem rozwoju osobowego. Jan Paweł II rozwój duchowy rozumial wlaśnie w perspektywie personalistycznej. Rozwój ten przedstawial w trzech glównych plaszczyznach: duchowość laikatu, duchowość kapłańska oraz duchowość osób konsekrowanych.

Przy tej okazji chcialbym wspomnieć o przeprowadzonych przeze mnie w drugiej polowie 2004 roku badaniach mlodzieży maturalnej odnoszących się do zagadnienia Kościola w Polsce w warunkach Unii Europejskiej. Badana mlodzież w adekwatny sposób zrozumiala pojęcie duchowości, o czym świadczą udzielone odpowiedzi, w których zawarte jest rozumienie duchowości jako podstawowego elementu ksztaltowania nie tyle osobowości co formacji czlowieka jako osoby. Duchowość tak rozumiana ksztaltuje życie publiczne, polityczne, naukowe, kulturowe i z tego powodu nie może być ukrywane w świecie prywatnym, osobistym czy tylko w zakrystii lub murach świątyń. Orędzie zbawienia niesione przez Chrystusa otwiera szansę budowania na ziemi Królestwa Bożego. Dokonywać się to może w milości, w tworzeniu cywilizacji milości oraz różnych formach rodzimej i europejskiej duchowości.

\footnotetext{
${ }^{75}$ Tamże, 51.

${ }^{76}$ T. P a s z k ow s k a, dz. cyt., s. 384.
} 